\section{Testing COVID-19 in Brazil: fragmented efforts and challenges to expand diagnostic capacity at the Brazilian Unified National Health System}

\author{
A testagem para COVID-19 no Brasil: esforços \\ fragmentados e desafios para ampliar a \\ capacidade diagnóstica no Sistema \\ Único de Saúde
}

\section{Testar para COVID-19 en Brasil: esfuerzos fragmentados y desafíos para expandir la capacidad diagnóstica en el Sistema Único de Salud}

\author{
Koichi Kameda 1,2 \\ Mady Malheiros Barbeitas 3 \\ Rosângela Caetano 4 \\ Ilana Löwy ${ }^{3}$ \\ Ana Claudia Dias de Oliveira 5 \\ Marilena Cordeiro Dias Villela Corrêa 4 \\ Maurice Cassier 3
}

doi: 10.1590/0102-311X00277420

\begin{abstract}
Since the first recorded case of COVID-19 on February 26, 2020, Brazil has seen an exponential growth in the number of cases and deaths. The national testing approach has been insufficient to correctly use this tool in the support of containing the epidemic in the country. In this communication, we discuss efforts and challenges to scale-up COVID-19 testing at the Brazilian Unified National Health System (SUS). This communication presents the initial results of the research project created to investigate the political, industrial, technological, and regulatory aspects that may affect the diagnostic and testing capacity for COVID-19 in Brazil. The paper draws on the review of academic literature, media publication, and collection of public data on tests purchase and regulation. It enlists initiatives to enhance PCR testing, national production and development of technologies, as well as regulatory measures to fast-track new tests. Our analysis indicates some points of reflection. Firstly, the lack of a consistent national strategy to fight COVID-19 exarcebated supply problems of diagnostic components. If the country was eventually able to circumvent this situation, it still faces a more structural dependency on the importation of diagnostic components. Secondly, the discontinued funding and distribution of tests may have implied health policy fragmentation and the growing importance of local governments and non-state actors to fighting the epidemics within SUS. Finally, initiatives established since the second semester of 2020 have expanded the testing capacity at SUS. However, it has not been sufficient to control the progress of the epidemic in the country.
\end{abstract}

COVID-19; Biotechnology; Diagnostic Tests; Universal Access to Health Care Services

\author{
Correspondence \\ K. Kameda \\ Centre Population et Développement. \\ 45 rue des Saints Pères, Paris / IdF - 75006, France. \\ kokameda@gmail.com \\ 1 Centre Population et Développement, Paris, France. \\ 2 Institut Francilien Recherche Innovation Société, Paris, France. \\ ${ }_{3}^{3}$ Centre de Recherche Médecine, Sciences, Santé, Santé Mentale \\ et Société, Paris, France. \\ 4 Instituto de Medicina Social, Universidade do Estado do Rio de \\ Janeiro, Rio de Janeiro, Brasil. \\ 5 Associação Brasileira das Indústrias de Química Fina, \\ Biotecnologia e suas Especialidades, Rio de Janeiro, Brasil.
}




\section{Introduction}

Since World Health Organization (WHO) called on all countries to ramp up their testing programs in order to slow the advance of the new coronavirus 1, we observed some examples of success in countries with different levels of development such as South Korea, Vietnam, Thailand, and Rwanda. These nations rapidly controlled the transmission, flattening the curve of cases. The South Korean government implemented a very rigid and repressive quarantine policy and an efficient contact tracing, but the availability of tests was undoubtedly a key element in the country's response. Previous work indicated some possible reasons for the rapid increase of test production and availability: political will and coordination, preparedness, and the existence of a strong national industry able to provide reagents 2 .

Since the first recorded case of COVID-19 on February 26, 2020, in Brazil, the country has seen an exponential growth in the number of cases and deaths. This serious public health issue is as much a matter of political will and lack of national coordination, as the underinvestment of the Brazilian Unified National Health System (SUS). The austerity policies for the last four years, in particular the 95 Constitutional Amendment setting a government expenditure ceiling for the next 20 years, has left SUS extremely vulnerable to address COVID-19 epidemic ${ }^{3}$.

Initiatives such as biotechnological enterprises, investments in new laboratory infrastructure and fast-track regulatory measures were launched to scale-up COVID-19 testing in Brazil. These fragmented efforts have congregated a set of heterogeneous actors: from regional/local governments (states and municipalities) to the private sector. The last Brazilian National Household Sample Survey - COVID-19 (PNAD COVID19), carried out by the Brazilian Institute of Geography and Statistics (IBGE) 4, indicates that 12,686 million PCR tests were performed by November 2020. This number represents an increase in COVID-19 testing but it is still low for a population of almost 213 million Brazilians 5 .

Considering this scenario, the project CoBRATestes - Testing Capacity for COVID-19 in Brazil: National Technological Production and Universal Access to Health in Times of Political Uncertainty funded by the French National Agency for Research on AIDS and Viral Hepatitis (ANRS) aims to investigate the political, industrial, technological, and regulatory aspects that may affect the diagnostic and testing capacity for SARS-CoV-2 in Brazil.

In this communication, we discuss the efforts to expand the offer of COVID-19 tests at SUS, as well as the major challenges to such initiatives. SUS is responsible for public health interventions and embraces more than $70 \%$ of the Brazilian population, representing a leading market for new biotechnologies on infectious diseases such as diagnostics and vaccines.

\section{Method}

This paper results from exchanges during the first months of CoBRATestes project. In this initial phase, the team has launched a platform to ease data collection, e.g., epidemiological reports, information on public purchase, gray and scientific literature, media articles. The platform also represents an effort to integrate a multidisciplinary network of Brazilian and French researchers who take part in the project team. The paper draws on this initial review of academic literature, media publication, and collection of public data on tests purchase and regulation.

The methodological approach to assess COVID-19 testing capacity in SUS is based in science and technology studies. It follows actors and action across different social worlds of science, industry, and the regulation of innovations 6 . Mixed methods are deployed, including interviews with key actors and observation in COVID-19 testing sites in Brazil. 


\section{Results}

\section{Initiatives to enhance the molecular testing capacity}

The testing strategy at SUS seems to be under continuous change. At the federal level, the government's strategy has prioritized testing in hospital and health care settings for symptomatic patients. A national testing program Diagnose to Care was launched in May with the goal to test $22 \%$ of the population 7 .

Initially, the network of central public health laboratories (LACENs) concentrated the PCR testing, with complementary support by the inclusion of laboratories from public universities and the network of HIV/AIDS viral load testing laboratories. The installation of four new PCR testing facilities further enhanced the testing capacity: two at the Oswaldo Cruz Foundation (Fiocruz) in Rio de Janeiro and Ceará; a facility in Curitiba at the Molecular Biology Institute of Paraná (IBMP) - a molecular biology institute connected to Fiocruz; and another one in a private network of laboratories (Diagnostics of America S.A. - DASA), in São Paulo. These efforts aim to increase testing capacity based on the model of public-private partnerships and the unprecedented contribution of donationbased funding. Together, these laboratories can process a million tests per month according to a public announcement 8 . Besides, some municipalities and states have developed their own testing strategies.

\section{National production and importation of testing components}

The supply of diagnostic components has affected the testing initiatives in several countries in the beginning of the pandemic. The burden was particularly high for developing countries since they need to compete with wealthier nations for reagents in the international market 9 .

The country presents a cluster of national private and public in vitro diagnostics (IVD) production. Since the 2000s, public production has been reinforced with investments to manufacture molecular kits and rapid platforms. PCR testing for COVID-19 at the LACENs has been assured by Fiocruz' biotech units (Institute of Technology in Immunobiologicals - Bio-Manguinhos - and the IBMP), by the mobilization of their molecular system, a model initially developed for blood screening. This system had already been employed during the Zika epidemics in the country 10 . Nevertheless, other biological components and platforms are outsourced from elsewhere, exposing more structural dependency in the IVD sector.

\section{Technological development}

Several research groups have announced R\&D activities for COVID-19 diagnostics. These groups are essentially public universities, research institutes, and private hospitals. They are targeting rapid, cheaper, and high performing tests compared to the ones available in the market. Besides that, there are some initiatives focused on reinforcing local production of diagnostics components.

\section{Regulatory measures}

The Brazilian Health Regulatory Agency (Anvisa) has implemented some measures to fast track market authorization of COVID-19 tests. By July 14, 2020, it had authorized 275 COVID-19 tests under an emergency use authorization. Other countries and regions have also implemented a similar mechanism. Brazil put this mechanisms in force to tackle Zika epidemic, which brought to the market many arboviruses tests. Such mechanisms intend to facilitate the availability of technologies during a public health emergency. However, concerns are raised over the reliability of some tests approved under these circumstances. Granting commercial authorization of rapid tests to pharmacies in April 2020 was another mechanism deployed to facilitate widespread use of diagnostic tests 11 . We plan to study the actual significance of these mechanisms in COVID-19 outbreak control. 


\section{Discussion}

We have enlisted initiatives aiming to expand the testing capacity to face COVID-19 in the SUS, as well as challenges that affect such efforts. Our analysis sheds light to the country's response to recent epidemics like HIV and Zika, and broadly to efforts in consolidating SUS in the last thirty years.

Firstly, this paper mentioned that the shortage of tests and reagents, in a first moment resulted from a lack of coordination and anticipation of reagent purchases by the country, as well as due to a simultaneous increase in the purchases at the global level. If the country was eventually able to circumvent this situation, it still faces a more structural dependency on the importation of diagnostic components. This issue was highlighted by Brazilian researchers and considered in the set of technological and industrial policies to reinforce the health care industrial complex ${ }^{12}$. These policies were later affected by the acute economic and political crises of the last four years and the adoption of fiscal austerity rules 13 . The lack of a consistent national strategy to fight COVID-19 only exacerbated supply problems of diagnostic components.

Secondly, the fragmented funding and distribution of tests displays the action of public health actors, universities, local health authorities, and hospitals but also of corporations and private banks in the absence of a nationally coordinated response during the first semester of 2020. This scenario may have implied health policy fragmentation and the growing importance of local governments and non-state actors in fighting the epidemics within the scope of SUS.

Finally, it is relevant to look at the Brazilian experience in fighting HIV/AIDS, even though the latter was shaped in a different political context regarding health, S\&T, and foreign relations policies. The national AIDS program played a major role in assuring access, technology evaluation, standardization, laboratory training, and procurement of HIV tests. Centralized procurement procedures were critical to optimize testing, allowing price negotiation and public manufacture to regulate the market 14. In the case of COVID-19, initiatives such as the new PCR testing facilities coordinated by Fiocruz have circumvented an initial lack of coordination. However, the expansion of the testing capacity has not been sufficient to control the progress of the epidemic in the country 15 .

\section{Contributors}

K. Kameda contributed to the study conception and design; data collection, analysis and interpretation; manuscript writing and review; and approved the final version of the manuscript, including the guarantee of its accuracy and integrity. M. M. Barbeitas contributed to the data collection, analysis and interpretation; manuscript writing and review; and approved the final version of the manuscript, including the guarantee of its accuracy and integrity. R. Caetano, I. Löwy, and A. C. D. Oliveira contributed to the data collection and interpretation and manuscript review; and approved the final version of the manuscript, including the guarantee of its accuracy and integrity. M. C. D. V. Corrêa and M. Cassier contributed to the study conception and design; data collection, analysis and interpretation; manuscript review; and approved the final version of the manuscript, including the guarantee of its accuracy and integrity.

\section{Additional informations}

ORCID: Koichi Kameda (0000-0003-1337-6501); Mady Malheiros Barbeitas (0000-0001-70154863); Rosângela Caetano (0000-0003-1480-2453); Ilana Löwy (0000-0001-6963-0578); Ana Claudia Dias de Oliveira (0000-0002-4250-1036); Marilena Cordeiro Dias Villela Corrêa (0000-0003-17428639); Maurice Cassier (0000-0003-3908-8073).

\section{Acknowledgments}

To the French National Agency for Research on AIDS and Viral Hepatitis (ANRS COV-28) and the French Institute of Research, Innovation and Society (IFRIS) for the financial support. 


\section{References}

1. World Health Organization. 2019 Novel Coronavirus (2019-nCoV): strategic preparedness and response plan. https://www.who.int/docs/ default-source/coronaviruse/srp-04022020. pdf (accessed on 15/Aug/2020).

2. Gaudillière J. Covid-19 et santé globale: la fin du grand partage? AOC 2020; 3 apr. https:// aoc.media/analyse/2020/04/02/covid-19-etsante-globale-la-fin-du-grand-partage/.

3. Barberia L, Gomez E. Political and institutional perils of Brazil's COVID-19 crisis. Lancet 2020; 396:367-8.

4. Instituto Brasileiro de Geografia e Estatística. PNAD COVID-19. https://covid19.ibge.gov. $\mathrm{br} / \mathrm{pnad}$-covid/saude.php (accessed on 19/ Sep/2020).

5. Instituto Brasileiro de Geografia e Estatística. Projeção da população do Brasil e das Unidades da Federação. https://www.ibge.gov.br/ apps/populacao/projecao/index.html (accessed on 19/Sep/2020).

6. Latour B. Ciência em ação: como seguir cientistas e engenheiros sociedade afora. São Paulo: Editora Unesp; 2011.

7. Cancian N, Lopes R. Governo 'recicla' plano de testagem e prevê diagnóstico clínico para Covid-19. Folha de S.Paulo 2020; 24 jun. https://www 1.folha.uol.com.br/cotidia no/2020/06/governo-recicla-plano-de-tes tagem-e-preve-diagnostico-clinico-paracovid-19.shtml.

8. Pereira ME. Após cinco meses, Brasil finalmente mira em ampliação de testes de Covid-19. Jornal de Brasília 2020; 23 aug. https://jornaldebrasilia.com.br/brasil/aposcinco-meses-brasil-finalmente-mira-em-am pliacao-de-testes-de-covid-19/.

9. Bradley J. In scramble for coronavirus supplies, rich countries push poor sside. The New York Times 2020; 9 apr. https://www.nytimes. com/2020/04/09/world/coronavirus-equip ment-rich-poor.html.
10. Kameda K. Testing the Nation: healthcare policy and innovation in diagnostic tests for infectious diseases in Brazil [Doctoral Dissertation]. Paris: École des Hautes Études en Sciences Sociales; 2019.

11. Agência Nacional de Vigilância Sanitária. Resolução RDC no 377, de 28 de abril de 2020. Autoriza, em caráter temporário e excepcional, a utilização de "testes rápidos" (ensaios imunocromatográficos) para a COVID-19 em farmácias, suspende os efeitos do $\$ 2$ o do art. $69 \mathrm{e}$ do art. 70 da Resolução de Diretoria Colegiada - RDC no 44, de 17 de agosto de 2009. Diário Oficial da União 2020; 29 abr.

12. Gadelha CAG, Quental C, Fialho BC. Saúde e inovação: uma abordagem sistêmica das indústrias da saúde. Cad Saúde Pública 2003; 19:4759.

13. Cassier M, Corrêa M. Health innovation and social justice in Brazil. London: Palgrave Macmillan; 2018.

14. d'Almeida C, Coriat B. A arquitetura do mercado de teste de monitoramento do HIV/aids e suas implicações sobre as respostas nacionais nos países em desenvolvimento. In: Possas C, Larouze B, organizadores. Propriedade intelectual e políticas públicas para o acesso aos antirretrovirais nos países do sul. Rio de Janeiro: Agence Nationale de Recherches sur le Sida/E-papers; 2013. p. 161-78.

15. Jassanoff S, Hilgartner S, Hurlbut JB, Özgöde O, Rayzberg M. Comparative Covid response: crisis, knowledge, politics. https://www.ingsa. org/covidtag/covid-19-commentary/jasanoffschmidt/ (accessed on 12/Jan/2021). 


\section{Resumo}

Desde que o primeiro caso de COVID-19 no Brasil foi notificado, em 26 de fevereiro de 2020, o país assiste a um crescimento exponencial no número de casos e mortes. A estratégia nacional de testagem tem sido insuficiente para usar essa ferramenta corretamente no apoio à contenção da epidemia no país. $O$ artigo discute os esforços e desafios para escalonar a testagem para COVID-19 no Sistema Único de Saúde (SUS). O texto apresenta os resultados iniciais de um projeto de pesquisa sobre os aspectos políticos, industriais, tecnológicos e regulatórios que podem afetar a capacidade diagnóstica e de testagem para COVID-19 no Brasil. O estudo se apoia em revisão da literatura cientifica, artigos publicados na mídia e coleta de dados públicos sobre a compra e regulamentação de testes. $O$ texto faz referência a iniciativas para ampliar a testagem de PCR, a produção nacional e o desenvolvimento de tecnologias, além de medidas regulatórias fast-track para novos testes. Nossa análise sugere alguns pontos para reflexão. Primeiro, a falta de uma estratégia nacional consistente para combater a COVID-19 agravou os problemas de fornecimento de reagentes de diagnostico num primeiro momento. Esta situação foi posteriormente resolvida, embora coloque novamente em pauta a dependência estrutural do país na importação de insumos de saúde estratégicos. Em segundo lugar, financiamento e a distribuição de testes, que ocorreram de forma descontinuada, podem indicar a fragmentação da política sanitária, assim como o papel de governos estaduais, municipais e atores não estatais no combate à epidemia no âmbito do SUS. Por último, iniciativas estabelecidas no segundo semestre de 2020 contribuíram para ampliar a capacidade de testagem molecular no SUS. Contudo, essa capacidade não foi suficiente para controlar a epidemia no Brasil.

COVID-19; Biotecnologia; Testes Diagnósticos; Acesso Universal aos Serviços de Saúde

\section{Resumen}

Desde que se registró el primer caso de COVID-19 el 26 de febrero de 2020, Brasil ha visto un crecimiento exponencial en el número de casos y muertes. La estrategia nacional para preconizar el test de diagnóstico ha sido insuficiente en el uso correcto de esta herramienta, con el fin de ayudar a contener la epidemia en el país. Se presentó los esfuerzos y los desafíos para ampliar la realización de pruebas de COVID-19 en el Sistema Único de Salud brasileño (SUS). Este artículo presenta los resultados iniciales del proyecto de investigación sobre los aspectos politicos, industriales, tecnológicos y regulatorios que pueden afectar la capacidad de diagnóstico para la COVID-19 en Brasil. El grupo de investigación realizó una revisión de la literatura académica, medios de comunicación y recogida de datos públicos respecto a la adquisición de tests y su regulación. Se haz referencia a iniciativas para promover la realización de pruebas de PCR, la producción nacional y el desarrollo de tecnologías, así como las medidas regulatorias fast-track para nuevas pruebas. Nuestro análisis indica algunos puntos de reflexión. Primero, la falta de una estrategia nacional consistente para luchar contra la COVID-19 que exacerbó los problemas de sumistro de los componentes de diagnóstico en un primer momento. Se solucionó posteriormente esta situación, aunque se coloque nuevamente en pauta la dependencia estructural del país en la importación de insumos de salud estratégicos. Segundo, la financiación y la distribución de tests de forma descontinuada pueden indicar la fragmentación de la política de salud, así como los gobiernos estaduales, municipales, $y$ atores no estatales asumiendo un rol preponderante en acciones de combate a la epidemia en el SUS. En último, las iniciativas establecidas en el segundo semestre del 2020 contribuyeron para ampliar la capacidad de realización de tests moleculares en el SUS. Sin embargo, esa capacidad no fue suficiente para controlar la epidemia en Brasil.

COVID-19; Biotecnología; Pruebas Diagnósticas; Acceso Universal a los Servicios de Salud
Submitted on $21 / \mathrm{Sep} / 2020$

Final version resubmitted on $03 / \mathrm{Feb} / 2021$

Approved on 08/Feb/2021 